\title{
Heavy Metals and Physicochemical Properties of Soils in Kano Urban Agricultural Lands
}

\author{
*1U.M. Dawaki, ${ }^{2}$ A.U. Dikko, ${ }^{2}$ S.S. Noma and ${ }^{3}$ U. Aliyu \\ 1Department of Soil Science, Bayero University, Kano \\ 2Department of Soil Science, Usmanu Danfodiyo University, Sokoto \\ 3Department of Crop Science, Usmanu Danfodiyo University, Sokoto \\ [Corresponding author: Email: mansurdawaki@yahoo.com; 䍖: +2348029029330]
}

\begin{abstract}
This study was conducted on the urban agricultural soils at the banks of three metropolitan and suburban rivers namely Challawa, Jakara and Watari in Kano, Kano State, Nigeria to determine the total, exchangeable and soluble concentrations of the heavy metals $\mathrm{Cu}, \mathrm{Cr}, \mathrm{Ni}, \mathrm{Zn}, \mathrm{Pb}$ and $\mathrm{Cd}$. The soils are all slightly alkaline (mean pH $7.42-7.77)$, with moderate CEC $(12.63-23.11 \mathrm{cmol} / \mathrm{kg})$, medium to high organic carbon $(7.16-11.27 \mathrm{~g} / \mathrm{kg})$. The mean ranges of total $\mathrm{Cu}, \mathrm{Cr}, \mathrm{Ni}, \mathrm{Zn}, \mathrm{Pb}$ and $\mathrm{Cd}$ were $4.95-5.99,5.85-$ $165.66,54.03-57.77,55.07-255.52,42.84-68.12$ and $0.59-11.81 \mathrm{mg} / \mathrm{kg}$ respectively. All the values were lower than the maximum allowable concentrations in soils, except for $\mathrm{Cd}$ at Jakara and Challawa. The mean ranges of exchangeable metals were $0.57-1.18,1.69-29.26,13.89-15.59,14.16-49.0110 .48-18.31$ and $0.39-1.20 \mathrm{mg} / \mathrm{kg}$ for $\mathrm{Cu}, \mathrm{Cr}, \mathrm{Ni}, \mathrm{Zn}, \mathrm{Pb}$ and $\mathrm{Cd}$ respectively. The mean soluble concentrations were 0.27 - 0.48, $0.61-15.91,5.60-7.15,4.90-17.42,2.78-9.36$ and $0.00-0.60 \mathrm{mg} / \mathrm{kg}$ for $\mathrm{Cu}, \mathrm{Cr}, \mathrm{Ni}, \mathrm{Zn}, \mathrm{Pb}$ and $\mathrm{Cd}$ respectively. Although appreciable amounts of all the metals were detected in the various forms, variability exists between the sites with concentrations found to be significantly higher $(p \leq 0.05)$ in areas irrigated with waters receiving industrial and domestic sewages namely, Challawa and Jakara than Watari which was the control and significant relationship ( $p \leq 0.05$ ) exists between exchangeable and total metal forms on one hand and such soil properties as organic carbon, available $\mathrm{P}$, total $\mathrm{N}$ and basic cations on the other.

Keywords: Heavy metals, bio-avaliable, Kano, Urban, Agriculture
\end{abstract}

\section{INTRODUCTION}

An understanding of the form of any soil pollutant and its dependence on soil's physico-chemical properties provides a basis for careful soil management that limits as far as possible, the negative impact of the pollutant on the ecosystem. Heavy metals in the soil have been classified into dissolved (in soil solution), exchangeable (in organic and inorganic components), as structural components of the lattices of soil minerals and insoluble precipitates with other soil components (Aydinalp and Marinova, 2003).

Of the various forms of heavy metals in the soil, of greatest concern are the exchangeable and the soluble, because these, are the forms that are available to plants (Calace et al., 2002). All negative effects of heavy metals start from their absorption by plants, and to a lesser extent by ground water contamination through leaching. As metals are absorbed by plants, they are thereby introduced into the food chain (Calace et al., 2002). Once metals are ingested through contaminated food, they pose all sorts of dangers to human health including hepatic diseases, aneamia, nausea etc (Calace et al., 2002); if the recommended daily allowances are exceeded. The effects of heavy metals in soil could be enormous. Major amongst them is their effects on microbial activities (Wyszkowska and Wyszkowska, 2002).
The use of wastewater for irrigation has for long been acknowledged as a source of metals into the soil. Kollender-Szych et al. (1998) showed soil concentration of some heavy metals in the Yellow river area of China to vary for $\mathrm{Cd}, \mathrm{Cr}, \mathrm{Pb}, \mathrm{Ni}$ and $\mathrm{Cu}$ across the profiles from the surface to the depth of $100 \mathrm{~cm}$. The average values for five sites were $135 \mathrm{mg} / \mathrm{kg}, \quad 82 \mathrm{mg} / \mathrm{kg}, \quad 41 \mathrm{mg} / \mathrm{kg}, \quad 82 \mathrm{mg} / \mathrm{kg}$ and $23 \mathrm{mg} / \mathrm{kg}$. Except for lead, all the other detected metals were outside the approved limit for German soils which were used as basis for comparison. Urban and peri-urban agriculture (UPA) (Binns et al., 2003) in Kano uses stream water that flows through industrialized and residential areas to irrigate vegetable crops. The impact of this land use system on the physical environment has not received much attention. Previous studies have established the presence of heavy metals in some of the areas due to this activity. A study of three irrigation sites in Kano Nigeria namely Jakara, Tomas and Tiga dams for $\mathrm{Cd}$, $\mathrm{Cr}, \mathrm{Cu}, \mathrm{Ni}$ and $\mathrm{Pb}$ in the soils indicated that the values ranged from $2.8-71 \mathrm{mg} / \mathrm{kg} \mathrm{Cd}, 15.3-24.6$ $\mathrm{mg} / \mathrm{kg} \mathrm{Cr}, 3.3-8.4 \mathrm{mg} / \mathrm{kg} \mathrm{Cu}, 19.6-27.9 \mathrm{mg} / \mathrm{kg} \mathrm{Ni}$ and $19.6-41.7 \mathrm{mg} / \mathrm{kg} \mathrm{Pb}$, all of which were appreciably higher than the expected values (Audu and Peacock, 2003). Binns et al. (2003) also detected heavy metals in the waters of the Jakara river while Ya'u, (1995) and Wakawa et al. (2008) detected these metals in some of the plants tissue grown in or 
around the Jakara and Challawa rivers. There is, however, little understanding of their forms in soil.

This paper aims to evaluate and compare the total and potentially bioavailable concentrations of some principal heavy metals namely $\mathrm{Cu}, \mathrm{Pb}, \mathrm{Cr}$, Ni and $\mathrm{Zn}$ in the irrigated soils around the Jakara and Challawa rivers whose waters are used in the irrigation and receive domestic and industrial effluents respectively.

\section{MATERIALS AND METHODS The study area}

This study was conducted at the banks of the Jakara, Challawa and Watari Rivers within the metropolitan Kano and its suburb. Site selection was based on difference in terms of effluent source into irrigation water. Jakara predominantly receives domestic effluents while Challawa receives industrial effluents. Watari is not associated with any wastewater and was therefore selected as control. All samples were collected in the area lying between latitude 11059' to $12^{\circ} 08^{\prime} \mathrm{N}$; and longitude $8^{\circ} 34^{\prime}$ to $8^{\circ} \mathrm{42}^{\prime} \mathrm{E}$. Three irrigation sites each (Yansama, Sharada and Rafin Kuka); (Akija, Airport Road and Magami); and (Lambu, Langel and BUK) respectively were selected to represent up, mid and downstream sectors of the Challawa, Jakara and the Watari rivers respectively. Global Positioning System (GPS) and ground reconnaissance were used for identification of sites and geo-referencing.

Kano is in the dry-sub-humid agro-ecological zone of Nigeria (Ojanuga, 2006). It is typically characterized by tropical wet and dry climate classified as Aw by W. Koppen (Olofin, 1987). The dominant geology is basement complex (Olofin, 1985; KNARDA, 1998). Ahmad (2008) has placed the dominant soil class of the area to be Alfisol according to the USDA soil taxonomy. The dominant crops irrigated in the areas are leafy vegetables such as lettuce and spinach.

\section{Sampling}

From each sampling area, the first 1ha under cultivation was selected. Stratified grid sampling method (Adepetu et al., 2000) was employed and $100 \mathrm{~m}$ long transect was taken parallel to the course of the river on the side with higher irrigation activity. $\mathrm{A}$ sample was collected at each $20 \mathrm{~m}$ distance along the transect from the surface 0 to $20 \mathrm{~cm}$. Four more transects were taken at $20 \mathrm{~m}$ parallel and subsequent to each other and were sampled similar to the first. A total of 25 samples were collected and composited into five samples at each zone of each of the three river banks.

\section{Laboratory Techniques}

Samples were air-dried, crushed and sieved through $2 \mathrm{~mm}$ sieve and subjected to laboratory analyses using standard procedures. The $\mathrm{pH}$ was determined using the 1:2.5 soil-distilled water ratio using EL model $720 \mathrm{pH}$ meter. The electrical conductivity (EC) was determined using 1:2.5 soil - distilled water ratio using Beckman Conductivity Bridge. Particle size analysis was done using the hydrometer method as outlined by Jaiswal (2004). The Walkley-Black wet oxidation method was used to determine organic carbon while ammonium acetate extraction and saturation techniques both as described in Adepetu et al. (2000) were used in determining CEC and exchangeable bases. Double acid digestion technique (Anderson, 1974) was used in sample extraction for total heavy metal determination. The fractions of heavy metals that are exchangeable and soluble were determined through the modified Tessier sequential extraction technique of Kashem et al. (2007) in which $1 \mathrm{~g}$ of each sample was mixed with $100 \mathrm{~cm}^{3}$ of de-ionized water. The resultant mixture was shaken for eight hours, left to stand overnight and then centrifuged for 15 minutes at $10.000 \mathrm{rpm}$. The supernatant liquid was decanted and used in the determination of the concentration of soluble metals in the soil. The residue from the soluble metal fraction was mixed with $100 \mathrm{~cm}^{3}$ of ammonium oxalate and shaken for eight hours at 10,000 rpm and left to stand overnight, centrifuged for 15 minutes and decanted. The solution was used to determine the fraction of metals in exchangeable form. All analyses were run in triplicates and the concentrations of the metals were determined using Atomic Absorption Spectrophotometer except $\mathrm{Na}$ and $\mathrm{K}$ that were determined using flame photometry.

\section{Statistical Techniquess}

The data obtained were subjected to both descriptive and inferential statistics. Analysis of variance (ANOVA) was used to compare means and significantly different means were separated using LSD; Pearson moment correlation analysis was also done to relate soil properties and the metals content in the soil all using SAS package 9.2 (SAS, 2007).

\section{RESULTS AND DISCUSSIONS \\ Physico-chemical properties of the soil}

Table 1 shows the physico-chemical properties of the soils of the three areas. The texture of the soils was sandy loam to loamy sand. The $\mathrm{pH}$ across the three areas can be interpreted as slightly alkaline (Esu, 1991). The mean EC values across the three areas are significantly different from one another with the highest value recorded at Jakara. The soils are 
neither sodic nor saline, but the alkaline $\mathrm{pH}$ and the high EC values at Jakara may potent salinity hazard; a problem which was also noted by Binns et al. (2003). The organic carbon contents across the three sites were all significantly different from one another $(p<0.05)$. They ranked from low in Watari and Challawa to medium in Jakara as earlier reportedby Esu (1991).

Using the rankings of Esu (1991) and Landon (1991) the calcium and magnesium contents of the soils ranged from medium at Watari, to high at both Jakara and Challawa. Potassium concentrations for all the three sites were within high to very-high range. Sodium concentrations were within the medium to high range, while the CEC values were within the medium ranges based on the rankings of Landon (1991).

The Nitrogen contents of the soils were high by the ranking of Landon (1991) with the value at Jakara site being significantly higher $(p<0.05)$ than both Watari and Challawa. The Phosphorus contents were within the medium at Watari to excessively high range at the Jakara and the Challawa sites. The mean values were all significantly different $(p<0.05)$ from one another, with the Jakara site having the highest value. The high amounts of $\mathrm{N}, \mathrm{P}$ and organic carbon in Jakara may be due to its association with domestic wastewater (FAO, 1992).

\section{Total heavy metals concentrations}

The total concentrations of the metals in the soil are shown in Table 1. The $\mathrm{Cu}$ and $\mathrm{Ni}$ contents were not significantly different between the three sites although the values of both were higher at the Jakara site. The mean $\mathrm{Cr}$ and $\mathrm{Zn}$ concentrations were significantly different from one another with the highest $\mathrm{Cr}$ content $(165.66 \mathrm{mg} / \mathrm{kg})$ recorded at Challawa basin and the highest Zn $(255.52 \mathrm{mg} / \mathrm{kg})$ content recorded at Jakara. The highest $\mathrm{Pb}$ concentration $(92.98 \mathrm{mg} / \mathrm{kg}$ ) was recorded at the Jakara basin which was different from that of Watari.

The mean $\mathrm{Cd}$ concentrations were all significantly different $(p<0.05)$ for the three sites with the highest mean $(11.81 \mathrm{mg} / \mathrm{kg})$ occurring at the Jakara site. The heavy metals concentrations are within the European Commission's recommended threshold values of 300 , $140,3,300,100$, and $75 \mathrm{mg} / \mathrm{kg} \mathrm{Zn,} \mathrm{Cu,} \mathrm{Cd,} \mathrm{Pb,} \mathrm{Cr}$ and $\mathrm{Ni}$ respectively as reported by Wild (1996) and DPR (2002) except for $\mathrm{Cd}$ at both Jakara and Challawa.

Table 1: Physicochemical Properties of the Soils of the Three Study Areas in Kano

\begin{tabular}{|c|c|c|c|c|}
\hline \multirow[b]{2}{*}{ Parameter } & \multicolumn{3}{|c|}{ Locations } & \multirow[b]{2}{*}{ SE \pm} \\
\hline & Challawa & $\overline{\text { Jakara }}$ & Watari & \\
\hline $\mathrm{pH}$ & $7.77 \mathrm{a}$ & $7.42 b$ & $7.48 \mathrm{~b}$ & 0.05 \\
\hline $\mathrm{EC}(\mathrm{mS} / \mathrm{m})$ & $1.79 \mathrm{~b}$ & $4.01 \mathrm{a}$ & $0.58 \mathrm{c}$ & 0.24 \\
\hline Sand (\%) & 76.29ab & $80.48 a$ & $73.41 \mathrm{~b}$ & 1.08 \\
\hline Silt (\%) & $16.88 \mathrm{a}$ & $14.56 \mathrm{a}$ & $18.48 \mathrm{a}$ & 0.91 \\
\hline Clay (\%) & 6.80ab & $4.96 \mathrm{~b}$ & $8.11 \mathrm{a}$ & 0.44 \\
\hline Textural Class & Sandy-loam & Loamy-sand & Sandy-loam & \\
\hline $\mathrm{Ca}(\mathrm{cmol} / \mathrm{kg})$ & $11.70 \mathrm{a}$ & $12.67 \mathrm{a}$ & $7.80 \mathrm{~b}$ & 0.66 \\
\hline $\mathrm{Mg}(\mathrm{cmol} / \mathrm{kg})$ & $2.85 a$ & $2.46 a$ & $2.15 a$ & 0.19 \\
\hline $\mathrm{K}(\mathrm{cmol} / \mathrm{kg})$ & $0.79 b$ & $1.85 a$ & $0.47 c$ & 0.12 \\
\hline $\mathrm{Na}(\mathrm{cmol} / \mathrm{kg})$ & $1.11 b$ & $3.20 a$ & $0.25 c$ & 0.21 \\
\hline $\mathrm{CEC}(\mathrm{cmol} / \mathrm{kg})$ & $19.15 a$ & $23.11 \mathrm{a}$ & $12.63 \mathrm{~b}$ & 1.07 \\
\hline Org. Carbon ( $\mathrm{g} / \mathrm{kg})$ & $8.07 \mathrm{~b}$ & $11.27 \mathrm{a}$ & $7.16 \mathrm{~b}$ & 0.56 \\
\hline$N(g / k g)$ & $0.76 \mathrm{~b}$ & $1.32 \mathrm{a}$ & $0.74 b$ & 0.04 \\
\hline$P(\mathrm{mg} / \mathrm{kg})$ & $77.67 \mathrm{~b}$ & $213.52 a$ & $31.73 c$ & 7.80 \\
\hline $\mathrm{Cu}(\mathrm{mg} / \mathrm{kg})$ & 4.95 & 5.99 & 5.06 & 2.05 \\
\hline $\mathrm{Cr}(\mathrm{mg} / \mathrm{kg})$ & $165.66 a$ & $112.61 \mathrm{~b}$ & $5.85 c$ & 16.05 \\
\hline $\mathrm{Ni}(\mathrm{mg} / \mathrm{kg})$ & 57.03 & 57.77 & 54.43 & 5.75 \\
\hline $\mathrm{Zn}(\mathrm{mg} / \mathrm{kg})$ & $149.03 b$ & $255.52 a$ & $55.07 \mathrm{c}$ & 23.97 \\
\hline $\mathrm{Pb}(\mathrm{mg} / \mathrm{kg})$ & $68.12 a b$ & $92.98 \mathrm{a}$ & $42.84 b$ & 13.84 \\
\hline
\end{tabular}

Despite the variability, the results are in close agreement with the findings of Audu and Peacock (2005) in the soils of the Jakara dam irrigation site in which the concentration of $\mathrm{Ni}, \mathrm{Cu}, \mathrm{Cr}$ and $\mathrm{Pb}$ were found to be appreciably high (up to $27.9 \mu \mathrm{gg}^{-1}$, $8.4 \mu \mathrm{gg}^{-1}, 24.6 \mu \mathrm{gg}^{-1}$ and $41.7 \mu \mathrm{gg}^{-1}$ respectively) and 
the work of Awode et al. (2008) at the Challawa valley where $\mathrm{Ni}$ and $\mathrm{Zn}$ concentrations were as high as 99.50 and $204.00 \mathrm{mg} / \mathrm{kg}$ respectively. The major causes of the presence of these elements in the study sites could be attributed to three factors; addition through fertilizers and agro-chemicals, their use in batteries, alloys, pigments, plastics and their discharge through domestic and industrial sewages from tanneries.

The higher concentration of $\mathrm{Cr}$ in Challawa could be due to the presence of industries especially tanning while the high $\mathrm{Zn}$ and $\mathrm{Pb}$ contents at Jakara could be due to high releases from domestic sewages and abattoir waste waters as reported by Maldanado et al. (2008); as well as contributions from exhaust releases by motor vehicles that are ever on the increase in the metropolis (Dawaki and Jazuli, 2007).

\section{Exchangeable and soluble metals concentrations}

The exchangeable and soluble concentrations of the metals are shown in Tables 2 and 3 respectively. Like the total concentration, the mean values of $\mathrm{Cu}$ were not significantly different for the two forms across the sites, while mean exchangeable $\mathrm{Cr}$ is significantly higher at Challawa and different from both Jakara and Watari which has the least. $\mathrm{Ni}, \mathrm{Zn}$ and $\mathrm{Pb}$ exchangeable and soluble contents at Jakara were significantly higher $(p<0.05)$ compared to either Challawa or Watari. The mean exchangeable $\mathrm{Cd}$ at the Watari site was significantly lower than either Jakara or Challawa; while none was detected in solution.

The principal factors that affect the behaviour of metals in the soil are $\mathrm{pH}$, nature and amount of clays and associated oxides, organic matter and nature of humic substances (Basta et al, 2005; Wahba and Zagloul, 2007). As most of the factors that affect the solubility and exchange behaviour of the metals in the soil are low to medium (especially clay and organic matter) that probably might have accounted for the low soluble and exchangeable concentrations despite the higher values in the total concentration (Basta et al., 2005).

Despite the high $\mathrm{Pb}$ concentration at the Jakara site, only small fractions were in exchangeable form even with the high organic matter content. The most probable explanation for this is that $\mathrm{Pb}$ may be strongly adsorbed by the organic fraction and thereby reducing its availability at the exchange complex. Yusuf (2007) and Adekola et al. (2010) reported higher amount of $\mathrm{Pb}$ as sorbed by organic matter than the amount found in exchangeable form. Of particular interest are low values of soluble $\mathrm{Pb}$ at the Jakara site in comparison to its total and exchangeable concentrations. Whereas higher amounts of total and exchangeable $\mathrm{Pb}$ were recorded at the site in comparison to the Challawa site (Tables 1 and 2), yet higher soluble $\mathrm{Pb}$ was detected at the Challawa site. The probable explanation for this behaviour of $\mathrm{Pb}$ is its association with the significantly high $\mathrm{P}$ at the Jakara (Table 1) most probably in the form of phosphate ions. Cao et al. (2009) stated that phosphate had been shown to be effective in immobilizing lead in contaminated soils via formation of stable lead phosphate minerals and they are particularly the most insoluble form of lead minerals in soils under a wide range of environmental conditions.

Table 2: Concentrations of Exchangeable Heavy Metals $(\mathrm{mg} / \mathrm{kg})$ in the Three Study Areas in Kano

\begin{tabular}{lllll}
\hline Heavy Metal & \multicolumn{4}{c}{ Site } \\
\cline { 2 - 5 } & Challawa & Jakara & Watari & SE \\
\hline $\mathrm{Cu}$ & 1.03 & 1.18 & 0.57 & 0.19 \\
$\mathrm{Cr}$ & $29.26 \mathrm{a}$ & $18.43 \mathrm{~b}$ & $1.69 \mathrm{c}$ & 1.97 \\
$\mathrm{Ni}$ & $14.63 \mathrm{a}$ & $15.59 \mathrm{a}$ & $13.89 \mathrm{a}$ & 0.77 \\
$\mathrm{Zn}$ & $33.30 \mathrm{~b}$ & $49.01 \mathrm{a}$ & $14.16 \mathrm{c}$ & 3.17 \\
$\mathrm{~Pb}$ & $18.31 \mathrm{a}$ & $16.07 \mathrm{ab}$ & $10.48 \mathrm{~b}$ & 1.42 \\
$\mathrm{Cd}$ & $1.12 \mathrm{a}$ & $1.20 \mathrm{a}$ & $0.39 \mathrm{~b}$ & 0.05 \\
\hline
\end{tabular}

Means followed by the same letter in the same column are not significantly different $(p \leq 0.05)$.

Table 3: Concentrations of Soluble Heavy Metals $(\mathrm{mg} / \mathrm{kg})$ in the Three Study Areas in Kano

\begin{tabular}{lllll}
\hline \multirow{2}{*}{ Heavy Metal } & \multicolumn{4}{c}{ Site } \\
\cline { 2 - 5 } & Challawa & Jakara & Watari & SE \\
\hline $\mathrm{Cu}$ & $0.48 \mathrm{a}$ & $0.27 \mathrm{a}$ & $0.39 \mathrm{a}$ & 0.07 \\
$\mathrm{Cr}$ & $15.91 \mathrm{a}$ & $7.00 \mathrm{~b}$ & $0.61 \mathrm{c}$ & 1.08 \\
$\mathrm{Ni}$ & $5.60 \mathrm{~b}$ & $7.15 \mathrm{a}$ & $6.03 \mathrm{~b}$ & 0.20 \\
$\mathrm{Zn}$ & $7.72 \mathrm{~b}$ & $17.42 \mathrm{a}$ & $4.90 \mathrm{~b}$ & 1.01 \\
$\mathrm{~Pb}$ & $9.36 \mathrm{a}$ & $7.90 \mathrm{a}$ & $2.78 \mathrm{~b}$ & 0.81 \\
$\mathrm{Cd}$ & $0.52 \mathrm{a}$ & $0.60 \mathrm{a}$ & $0.00 \mathrm{~b}$ & 0.029 \\
\hline
\end{tabular}

Means followed by the same letter in the same column are not significantly different $(p \leq 0.05)$.

The effect of clay, organic matter and $\mathrm{pH}$ could be observed on the exchangeable and soluble concentrations of $\mathrm{Cd}$ especially at the Challawa and the Jakara sites. At the Jakara site, the exchangeable and soluble concentrations were additionally affected by total concentration. Similar effect of concentration, organic matter and clay could be observed. $\mathrm{Cd}$ is a highly mobile ion (Tokaliolu et al., 2003) but here it showed relatively low mobility to the exchange complex in comparison to the total amount in the soil across all the sites. The most probable explanation 
for the relatively low amounts in this work may be due to sorption by the organic matter which is a possible reverse of behaviour for $\mathrm{Cd}$ especially in soils where $\mathrm{pH}$ is slightly alkaline to alkaline (Basta et al,. 2005).

$\mathrm{Cu}$ is a metal that is predominantly adsorbed at the top soil by clay and/or organic matter, and for most of the metals, this adsorption increases with increasing pH (Wild, 1996). This fact may validate the results here especially when compared with organic matter contents of the areas shown in Table 1. In most of the sampling locations appreciable organic matter occurs and the $\mathrm{pH}$ values were slightly alkaline so also the exchangeable values of the metal was also high. Reichmann (2002) stated that the amount of organic matter in the soil can also be a more important factor on $\mathrm{Cu}$ solubility than $\mathrm{pH}$ or any other factor. Despite the higher total concentration and exchangeable forms at the Jakara site, lower amount was detected in solution compared to the Challawa sectors. This is because some of what was detected as total and exchangeable at the site might have probably been sorbed by the high organic matter content in the site. The equally lower $\mathrm{pH}$ at the site compared to the Challawa basin might have facilitated the sorption process.

The most important factor that could have affected the concentration of the exchangeable and soluble $\mathrm{Cr}$ according to this result could be the total concentration and $\mathrm{pH}$. This is typified in all the sites but more especially at the Challawa site. The predominant form of $\mathrm{Cr}$ in the soil is $\mathrm{Cr}$ (III) which is highly stable. As explained by Zayed and Terry (2003) with increasing $\mathrm{pH}$ their solubility tends to increase. The variability of $\mathrm{Cr}$ solubility and exchangeability here tally well with the findings of Ogbo and Okhouya (2011) in crude oil contaminated soils remediated with mushroom plants and the theory of Basta et al. (2005).

The effect of total concentration on the exchangeable form of $\mathrm{Ni}$ could also be seen. The high Ni content in the sectors has reflected in its exchangeable form. Similarly, the exchange property of this metal has also been affected by clay and organic matter in addition to the total concentration. The effect of clay content could be observed at the Watari site where despite the lower organic matter content compared to the other two sites, it had appreciable amounts of $\mathrm{Ni}$ in exchange complex because of its relatively better clay content. In the cumulative means, the combined effect of concentration, better organic matter content and reasonable clay content in some of its sectors has given the Jakara basin higher amount of $\mathrm{Ni}$ in exchangeable form. Significant movement of nickel within the soil matrix and into other media is likely to occur under acidic conditions. This fact is the most obvious factor that affects its solubility here. Despite the relatively high amount of this metal in all the sectors of the sites and its availability in exchange, lesser amounts were detected in all the locations because in all the locations $\mathrm{pH}$ tend to incline towards alkalinity which does not favour Ni solubility. McBride et al. (2004) reported that all soil amendments that raise $\mathrm{pH}$ reduce the solubility of $\mathrm{Ni}$ and thereby its extractability from the bio-available fraction.

The exchangeable $\mathrm{Zn}$ concentration seems to be predominantly affected by organic matter and total concentration as the amounts decreases in the trend of Jakara > Challawa > Watari much as organic matter. The effect of concentration on the exchangeable $\mathrm{Zn}$ content was as reported by Zhao et al. (2010): values increasing with increasing total concentration. Exchangeable $\mathrm{Zn}$ and $\mathrm{CO}_{3}{ }^{2-}$ associated $\mathrm{Zn}$ were high at the sites where organic matter was high in the work of Yusuf (2007) despite the fact that a substantial concentration of it was also found bound (sorbed) to the organic matter. This was in accord with the findings of Muhammad (2006) in irrigated soils in Kano where exchangeable fraction in areas with high organic matter relates almost linearly. Basta et al. (2005) reported interaction with other ions as affecting the bioavailable concentrations of $\mathrm{Zn}$ in the soil. Contrary to the high total $\mathrm{Zn}$ concentration across all the sectors of the sites (Table 1), much lower concentration was found in soluble form across all the sectors of the sites. McBride et al. (2004) have shown that alkaline soils produced low $\mathrm{Zn}$ extractability, in consistence with the high soil $\mathrm{pH}(\geq$ 8). Siebielec (2006) attributed poor total $\mathrm{Zn}$ contribution to soluble and other bio-available forms to the fact that most $\mathrm{Zn}$ is mostly present as adsorbed or occluded by $\mathrm{Fe}$ and Mn oxides (on average 28.6 and $55.1 \%$ of total $\mathrm{Zn}$ ) and this increases with increasing $\mathrm{pH}$. This explains why Jakara basin with its higher total concentration and relatively lower $\mathrm{pH}$ also had more soluble $\mathrm{Zn}$ across its sectors especially the midstream sector.

\section{Relationship between metals and soil properties}

The relationship between the metals analyzed and some of the soil properties is shown in Table 4. Total and exchangeable metals were correlated with some soil properties which included clay content, $\mathrm{pH}$, total $\mathrm{N}$, organic carbon, available $\mathrm{P}, \mathrm{Ca}, \mathrm{Mg}, \mathrm{K}, \mathrm{Na}$ and CEC. Negative relationship was shown by both total and exchangeable forms of all the metals with clay content which was significant with Total $\mathrm{Zn}, \mathrm{Pb}$ and 
$\mathrm{Cd}$; and with all exchangeable forms except $\mathrm{Cu}$. Similar trend was observed with $\mathrm{pH}$ except with exchangeable $\mathrm{Cr}$ and $\mathrm{Ni}$ which were positive but insignificant. The negative relationship with $\mathrm{pH}$ was only however significant with Total $\mathrm{Cu}, \mathrm{Zn}, \mathrm{Pb}$ and Ex. Zn. The relationship of both metal forms was positive and significant with Total $\mathrm{N}$, organic carbon and $\mathrm{P}$ except Ex. Ni which was negative but insignificant and Ex. Pb which was positive but insignificant. Both forms of the metals related significantly with cations and CEC, although negatively and insignificantly between $\mathrm{Na}, \mathrm{Ca}$ and Total $\mathrm{Cu}$; $\mathrm{Ca}, \mathrm{Mg}, \mathrm{Na}, \mathrm{CEC}$ and Total $\mathrm{Ni} ; \mathrm{K}$, and Exchangeable Ni.

The results here portray a variable behavioural pattern for the elements. The low clay content in the soil as shown in Table 1 has significantly affected the relationship of the two forms of the metals with it, especially the exchangeable forms which were supposed to have shown closer association with it. This was however favourably compensated by the high organic matter content of the soil as shown by the largely positive relationship with it. The affinity of the metals for exchangeability and retention is largely towards either organic matter or clay and therefore the dominance of organic matter over clay in the soil played a significant role in regulating the two forms of the metals. The particular affinity of Ni for clay sites might have influence its relationship with the clay content in the soil. The result here deviates from the findings of Abdu (2010) for similar soils due particularly to the higher clay contents of his soil. The slightly alkaline nature of the soil here strongly influenced the relationship between the metals and the $\mathrm{pH}$ of the soil. This is because moderately acidic $\mathrm{pH}$ tends to favour the exchangeable and other forms of heavy metals in the soil as observed by by Manta et. al. (2002) and Tume et. al. (2006). The largely significant relationship between metals and cations on one hand and metals and $\mathrm{P}$ and $\mathrm{N}$ on the other could have been influenced by an association at the level of the parent material and nutrient incorporation and release in the case of $\mathrm{N}$. This association is probable due to the variable composition of the basement complex formation (Ahmad, 2008) from which this soil was formed as well as the high organic matter content in the soil especially at the Jakara sites (Table 1). Metallic association with other cations and anions in the soil is a common phenomenon especially in slightly acidic to slightly alkaline soil (Yusuf, 2007). Similar observation was made by Abdu (2010).

Table 4: Relationship between total $(T)$ and exchangeable (Ex.) metals with some soil parameters

\begin{tabular}{|c|c|c|c|c|c|c|c|c|c|c|c|c|}
\hline & T. Cu & T. $\mathrm{Cr}$ & T. Zn & T. Ni & T. Pb & T. Cd & Ex. Cu & Ex. $\mathrm{Cr}$ & Ex. Zn & Ex. Ni & Ex. Pb & Ex. Cd \\
\hline Clay & -0.024 & -0.158 & $-0.429^{* *}$ & 0.115 & $-0.344^{\text {*k }}$ & $-0.327^{\text {t* }}$ & -0.050 & $-0.187^{\star}$ & $-0.388^{* * t}$ & $0.178^{*}$ & $-0.217^{\star}$ & $-0.225^{* \star}$ \\
\hline $\mathrm{pH}$ & $-0.204^{*}$ & 0.142 & $-0.273^{* *}$ & -0.062 & $-0.248^{\text {*t }}$ & -0.046 & -0.158 & 0.158 & $-0.303^{\text {*t }}$ & 0.109 & -0.079 & -0.020 \\
\hline TN & $0.174^{*}$ & $0.226^{* *}$ & $0.594^{* *}$ & $0.201^{*}$ & $0.359^{* *}$ & $0.445^{\star \star}$ & $0.225^{* *}$ & $0.192^{*}$ & $0.571^{* *}$ & -0.038 & 0.144 & $0.375^{\star \star}$ \\
\hline OC & $0.193^{*}$ & $0.195^{\star}$ & $0.478^{* *}$ & 0.045 & $0.246^{* *}$ & $0.403^{* *}$ & $0.245^{* \star}$ & 0.132 & $0.422^{* *}$ & -0.137 & 0.102 & $0.310^{* *}$ \\
\hline$P$ & $0.216^{*}$ & $0.345^{\star \star}$ & $0.835^{* k}$ & 0.091 & $0.464^{* *}$ & $0.675^{\star *}$ & $0.277^{* *}$ & $0.317^{\star \star}$ & $0.743^{* k}$ & -0.109 & 0.148 & $0.485^{\star *}$ \\
\hline $\mathrm{Ca}$ & -0.023 & $0.451^{* *}$ & $0.509^{* *}$ & -0.142 & $0.368^{\star *}$ & $0.493^{* *}$ & 0.027 & $0.496^{* *}$ & $0.533^{* *}$ & $-0.356^{* *}$ & $0.362^{* *}$ & $0.448^{* *}$ \\
\hline $\mathrm{Mg}$ & 0.069 & $0.315^{\star *}$ & $0.246^{* *}$ & -0.089 & $0.251^{* \star}$ & $0.183^{*}$ & 0.075 & $0.367^{\star *}$ & $0.312^{* *}$ & $-0.273^{* \star}$ & $0.325^{* *}$ & 0.146 \\
\hline K & $0.190^{*}$ & $0.337^{\star \star}$ & $0.729^{* *}$ & 0.080 & $0.508^{* *}$ & $0.646^{* k}$ & $0.225^{* k}$ & $0.308^{* *}$ & $0.655^{* k}$ & -0.072 & $0.230^{* *}$ & $0.516^{* *}$ \\
\hline $\mathrm{Na}$ & -0.020 & $0.353^{* *}$ & $0.758^{* *}$ & -0.008 & $0.422^{* *}$ & $0.646^{* *}$ & 0.064 & $0.374^{* *}$ & $0.655^{* *}$ & $-0.175^{\star}$ & $0.177^{\star}$ & $0.448^{* *}$ \\
\hline CEC & 0.027 & $0.505^{* *}$ & $0.657^{\text {k* }}$ & -0.057 & $0.440^{* *}$ & $0.600^{* *}$ & 0.079 & $0.541^{* *}$ & $0.654^{* *}$ & $-0.299^{* *}$ & $0.363^{* *}$ & $0.506^{* \star}$ \\
\hline
\end{tabular}

\section{CONCLUSION}

The results show that the soils of the studied areas are at risk of contamination from these metals, especially given the high total concentrations which are gradually being released into exchange and subsequently into solution and probable absorption into the plants system. This is especially given the low to medium values of $\mathrm{CEC}$, organic matter, clay and the slightly alkaline nature of the $\mathrm{pH}$; as well as the higher levels of the metals detected at some sites of the study. The tendency for their bioavailability may also not be ruled out as appreciable contents have also been detected in exchangeable fractions which may likely affect the content in solution from which plants absorbs.

\section{Recommendation}

Based on the findings it could be recommended that an improvement of the soils' organic matter content through incorporation of non-pollutant sources of 
carbon such as animal manure may reduce the tendency of metals for bioavailability. This is evident in the case of Jakara which despite of its high total metal content has appreciably low bioavailable forms due to its relatively high organic matter. Furthermore an irrigation management system that encourages other water sources such as underground water may also be recommended to reduce the rate of introduction of the pollutants through wastewater.

\section{REFERENCES}

Abdu, A. (2010). Availability, transfer and balances of heavy metals in urban agriculture of West Africa. Unpublished Ph. D. Thesis accepted by University of Kassel for acquiring the academic degree of Doktor der Agrarwissenschaften (Dr. agr.).

Adekola, F.A., Abdus-Salam, N., Bale, R.B. and Oladeji, I.O. (2010). Sequential extraction of trace metals and particle size distribution studies of Kainji lake sediment, Nigeria. Chemical Speciation and Bioavailability, 22(1): $43-49$.

Adepetu, J.A., Nabhan, H. and Osinubi, A. (Eds) (2000). Simple soil, water and plant testing techniques for soil resource management: proceedings of a training course held in Ibadan, Nigeria. 16-27 September 1996. IITA, Ibadan.

Ahmad, K.A (2008). The Kano Physical Environment. www.kanostate.net, accessed February, 2009.

Anderson, J. (1974). Wet Digestion versus Dry for the Analysis of Fish Tissue for Trace Metals. Afon Absorption Newsletter; 11: 88-89.

Audu, A.A. and Peacock, C.J. (2005). Irrigation as a source of soil pollution in the Sudan-Sahel region of Northern Nigeria; Tropical Environmental Research, (6): $414-417$.

Awode, U.A., Uzairu. A., Balarabe, M.L., Harrisson, G.F.S. and Okunola, O.J. (2008). Assessment of Peppers and Soils for Some Heavy Metals from Irrigated Farmlands on the Bank of River Challawa, Northern Nigeria. Pakistan Journal of Nutrition 7(2): 244-248.

Aydinalp, C. and Marinova, S. (2003). Distribution and Forms of Heavy Metals in Some Agricultural Soils. Polish Journal of Environmental Studies, 12(5): 629-633.

Basta, N.T., Ryan, J.A. and Chaney, R.L. (2005). Trace Element Chemistry in Residual-Treated Soil: Key Concepts and Metal Bioavailability. Journal of Environment Quality, 34: 49-63.

Binns, J.A., Machonachie, R.A. and Tanko, A.I. (2003). Water, Land and Health in Urban and Peri-Urban Food Production: The Case of Kano,
Nigeria. Land Degradation Development 14: $431-444$.

Calace, N., Petronio, B.M., Picciolo, M. and Pietroletti, M. (2002). Heavy Metals Uptake by Barley Growing in Polluted Soils: Relationship with Heavy Metals Speciation in Soils. Soil Science-Plant Analysis 33(1 \& 2): 103-115.

Cao, X., Wahbi, A., Mab, L., Li, B. and Yang, Y. (2009). Immobilization of $\mathrm{Zn}, \mathrm{Cu}$, and $\mathrm{Pb}$ in contaminated soils using phosphate rock and phosphoric acid. Journal of Hazardous Materials, 164: 555-564.

Dawaki, U.M. and Jazuli, A. (2007). Irrigation and Heavy Metals Pollution in Soil under Urban and Peri-urban Agricultural System. International Journal of Pure and Applied Sciences, 1(3): 3742.

Department of Petroleum Resources (DPR) (2002). Environmental guidelines and Standards for the petroleum industries in Nigeria. Department of Petroleum Resources, Abuja, Nigeria: Ministry of Petroleum and Mineral Resources.

Esu, I.E. (1991). Detailed Soil Survey of NIHORT Farm at Bunkure, Kano State, Nigeria. Institute for Agricultural Research, Ahmadu Bello University, Zaria.

FAO, (1992). Waste water treatment and use in agriculture. Irrigation and Drainage paper 47; FAO Rome.

Jaiswal, P.C. (2004). Soil, Plant and Water Analyses. Indhiana, Kalyani Publishers, India, 437pp.

Kano Agricultural and Rural Development Agency (KNARDA) (1998). Soil and Water Quality Analysis Report. Kano, KNARDA/National Fadama Development Project.

Kashem, M.A., Singh, B.R., Kondo, T. Imamul Huq, S.M. and Kawai, S. (2007). Comparison of extractability of $\mathrm{Cd}, \mathrm{Cu}, \mathrm{Pb}$ and $\mathrm{Zn}$ with sequential extraction in contaminated and noncontaminated soils, International Journal of Environmental Science and Technology, 4(2): 169-176.

Kollender-Szych, A., Breburda, J., Felix-Henningsen, P. and Troth, H. (1998). Heavy Metals Pollution of Irrigated Soils in Ningxia, China. Advances in Geo-ecology, 31(2): 697-704.

Landon, J.R. (ed) (1991). Booker Tropical Soil Manual. John Wiley and Sons Inc.; New York, 465pp.

Maldonado, V.M., Rubio Arias, H.O., Quintana, R., Saucedo, R.A., Gutierrez, M., Ortega, J.A. and Nevarez, G.V. (2008). Heavy Metal Content in Soils under Different Wastewater Irrigation Patterns in Chihuahua, Mexico. International 
Journal of Environmental Research and Public Health, 5(5): 441-449.

Manta, D.S., Angelone, M., Bellanca, A., Neri, R. and Spovieri, R. (2002). Heavy metals in urban soils: a case study from the city of Palermo (Sicily), Italy. Science of the Total Environment 30: 229 -243 .

McBride, M.B., Richards, B.K. and Steenhuis, T. (2004). Bioavailability and crop uptake of trace elements in soil columns amended with sewage sludge products. Plant and Soil, 262: 71-84.

Muhammad, M.I. (2006). Analytical Studies of Soil Characteristics from Five Irrigation Areas of Kano State. An Ph.D Thesis Submitted to the Department of Chemistry, Faculty of Science, Bayero University, Kano (Unpublished).

Ogbo, E.M. and Okhuoya, J. (2011). Bioavaialability of some heavy metals in crude oil contaminated soils remediated with Pleurotus tuber-regium Fr. Singer. Asian Journal of Biological Sciences, 4(1): 53-61.

Ojanuga, A.G. (2006). Agroecological Zones of Nigeria Manual. Abuja, Federal Ministry of Agriculture and Rural Development, 124pp.

Olofin, E.A. (1985). Human Responses to the Natural Environment in the Kano Region in Barkindo, A.A. (1985). Kano and its Neighbours. Zaria, ABU Press, 216pp.

Olofin, E.A. (1987). Some aspects of the physical geography of the Kano region and related human responses. BUK Press, Kano, Nigeria.

Reichman, S.M. (2002). The Responses of Plants to Metal Toxicity: A review focusing on Copper, Manganese and Zinc. Occasional Paper No.14. The Australian Minerals \& Energy Environment Foundation, Melbourne, Victoria.

Sahoo, S.K. and Klopka, S.M. (1985). Determination of Heavy Metals in Effluents from Bompai Industrial Area, Kano, Nigeria. Indian Journal of Environmental Protection, 4: 257-261.

SAS (2007). SAS package 6.0. SAS Institute Inc., Cary, NC.

Siebielec, G., Stuczyński, T. and KorzeniowskaPucułek, R. (2006). Metal Bioavailability in
Long-Term Contaminated Tarnowskie Gory Soils. Polish Journal of Environmental Studies 15(1): 121-129.

Tokaliolu, S., Karlal, S. and Birol, G. (2003) Application of a three-stage sequential extraction procedure for the determination of extractable metal contents in highway soil. Turkish Journal of Chemistry, 27: 333-346.

Tume, P., Berch, J., Longan, L., Tume, L., Reverter, F. and Sepulveda, B. (2006). Trace elements in natural surface soils in Sant Climent (Catalonia, Spain). Ecological engineering, 27: 145-152.

Wahba, M.M. and Zaghloul, A.M. (2007). Adsorption Characteristics of Some Heavy Metals by Some Soil Minerals. Journal of Applied Sciences Research, 3(6): 421-426.

Wakawa, R.J., Uzairu, A., Kagbu, J.A. and Balarabe, M.L. (2008). Impact assessment of effluent discharge on physico-chemical parameters and some heavy metal concentrations in surface water of River Challawa Kano, Nigeria. African Journal of Pure and Applied Chemistry, 2(10): 100-106.

Wild, A. (1996). Soils and Environment: An Introduction. Cambridge University Press; Cambridge, 290pp.

Wyszkowska, J. and Wyszkowski, M. (2002). Effects of Cadmium and Magnesium on Microbial Activities in Soils. Polish Journal of Environmental Studies, 11(5): 585-591.

Ya'u, M. (1995). Determination of the Concentration of Some Elements in Edible Plants Grown at Jakara Dam Irrigation Area of Kano State, an M.Sc. thesis, Department of Chemistry, BUK, Kano (Unpublished).

Yusuf, K.A. (2007). Sequential Extraction of Pb, Cu, $\mathrm{Zn}$ and $\mathrm{Cd}$ in Soils near Ojota Waste Site. Journal of Agronomy, 6(2): 331-337.

Zayed, A.M. and Terry, N. (2003). Chromium in the environment: factors affecting biological remediation. Plant and Soil, 249: 139-156.

Zhao, Y., Zhifan, C., Qiang L. and Xitao L. (2010). $19^{\text {th }}$ World Congress of Soil Science, Soil Solutions for a Changing World 1 - 6 August 2010, Brisbane, Australia. Published on DVD 